\title{
PROSPECTS OF CCS PROJECTS IMPLEMENTATION IN RUSSIA: ENVIRONMENTAL PROTECTION AND ECONOMIC OPPORTUNITIES
}

\author{
Pavel Tcvetkov ${ }^{1}$, Alexey Cherepovitsyn ${ }^{1}$ \\ 1 National Mineral Resources University (Mining University), Vasil'evsky Ostrov, 21 liniya 2, Saint-Petersburg, \\ 199106 Russia, e-mail: pscvetkov@yandex.ru, alekseicherepov@inbox.ru
}

Received: 2016.02.14

Accepted: 2016.03.04

Published: 2016.04.01

\begin{abstract}
The urgency of environmental protection is determined by its intensive change because of human impact, which, among other things, accompanied by an increasing of carbon dioxide $\left(\mathrm{CO}_{2}\right)$ emissions. One of the ways to reduce the emission is Carbon Capture and Storage (CCS) technologies. To date, developed countries have successfully implemented a number of CCS demonstration projects. Their main purpose is to study the effectiveness of $\mathrm{CO}_{2}$ storage. Russia is one of the world's largest producers of $\mathrm{CO}_{2}$ emissions. However, $\mathrm{CO}_{2}$ capture and storage issues are not studied by Russian enterprises due to the absence of environmental taxes. The experience of developed countries shows that $\mathrm{CO}_{2}$ storage projects, in addition to the reduction of anthropogenic impact, can be commercially effective not only by reducing the tax burden. This review presents the analysis of international experience in the field of $\mathrm{CO}_{2}$ capture and storage. Given the immaturity of technology and lack of the necessary volume of statistical data, it was an attempt to determine the minimum conditions, which permit the implementation of CCS projects in Russian oil fields. On the basis of the Russian development forecast and the fuel balance structure the volumes of $\mathrm{CO}_{2}$ emissions in the 2016-2030 years were calculated. According to significant difference in opinions about the feasibility of CCS implementation in Russia, this review presents the main arguments for and against such projects. Evaluation of the potential effectiveness of CCS projects to enhance oil recovery factor showed that in spite of the absence of $\mathrm{CO}_{2}$ emissions taxes, such projects could be commercially effective in Russia due to the increase in oil recovery.
\end{abstract}

Keywords: environment, $\mathrm{CO}_{2}$ emission, sequestration, carbon capture and storage, oil recovery factor.

\section{INTRODUCTION}

For the first time the issues related to global warming and the greenhouse effect became public in 1960 in connection with the data collected by Manua Loa Observatory, Hawaii [Keeling 1978]. In 1988, under the auspices of the United Nations Environment Programme (UNEP) and the World Meteorological Organization (WMO), the Intergovernmental Panel on Climate Change (IPCC) was set up to assess the risks of global climate change [Hulme and Mahony 2010], and in 1992 the United Nations Framework Convention on Climate Change (UNFCCC), which is aimed at global climate change controlling [Meakin
1992], was approved. In 2005 the Kyoto Protocol came into effect, which identified the need of greenhouse gas emissions reduction (from 2008 to 2012 by $5.2 \%$ compared to 1990 levels). In 2012 in Doha (Qatar), it was decided to extend the Kyoto Protocol up to 2020 [Doha Climate Change 2012].

Thus, the world community faced the problem of finding ways to reduce greenhouse gas emissions (primarily $\mathrm{CO}_{2}$ ), not compromising industry and the standard of living. The main ways of reducing emissions of greenhouse gases are reducing energy consumption, improving the efficiency of traditional energy (Table 1), development of renewable and nuclear energy 
Table 1. $\mathrm{CO}_{2}$ emissions from fossil fuels combustion [European Commission, 2006]

\begin{tabular}{|l|c|}
\hline \multicolumn{1}{|c|}{ Fuel } & $\mathrm{CO}_{2,}$ emissions [tons/thousand J] \\
$(\mathrm{g} / \mathrm{kW} \cdot \mathrm{h})$
\end{tabular}

[Khlebnikov et al. 2009]. These options assume profound reconstruction of energy, which is a very capital-intensive and knowledge-intensive process, and the period of its implementation, even in developed countries, takes decades. Furthermore, it cannot solve the problem of climate change completely despite the fact that such technologies as biomass pyrolysis allows to transfer up to $63 \%$ of the original carbon in the fixed form [Borodulya et al. 2004], which greatly facilitates the process of gas utilization [Burcu 2013] and opens alternative ways for its use [Tcvetkov and Strizhenok 2016].

One of the proposed solutions to solve this problem is Carbon Capture and Storage (CCS). The technology involves capturing carbon dioxide and other carbon compounds, and their long-term storage in special reservoirs [Leung et al. 2014]. CCS is possible to apply to the exist- ing energy system based on fossil fuel, which makes the reduction of greenhouse gas emissions cheaper in the short term compared to other technologies (reduction of the fossil fuels share, developing nuclear and renewable energy, etc.) [L'Orange Seigo 2014]. Despite the relative novelty of this solution, some of its units have already been used in the industry of various countries, as pilot or even commercial projects (Figure 1).

Not all sources of carbon dioxide emissions are possible to adopt with CCS technology. About half of all $\mathrm{CO}_{2}$ emissions, mostly originating from the combustion of fossil fuels (coal, gas, oil, etc.), the production of cement, oil and gas processing, as well as in the smelting of iron and steel [CCES 2014] are potentially suitable to capture.

Top countries in terms of $\mathrm{CO}_{2}$ emissions volume are China, US, EU, India and Russia (Figure 2 ), where the major part of emissions occur due to the processing of coal and petroleum products [IEA 2015].

However, if the developed countries such as the United States (the emission was reduced by $10 \%$ in 2012 compared to 2000) and the EU (by 5\%) conduct research activity in the field of CCS technologies, China, India and Russia, yet do not pay enough attention to this problem and do not reduce their emissions (emission in these countries doubled).

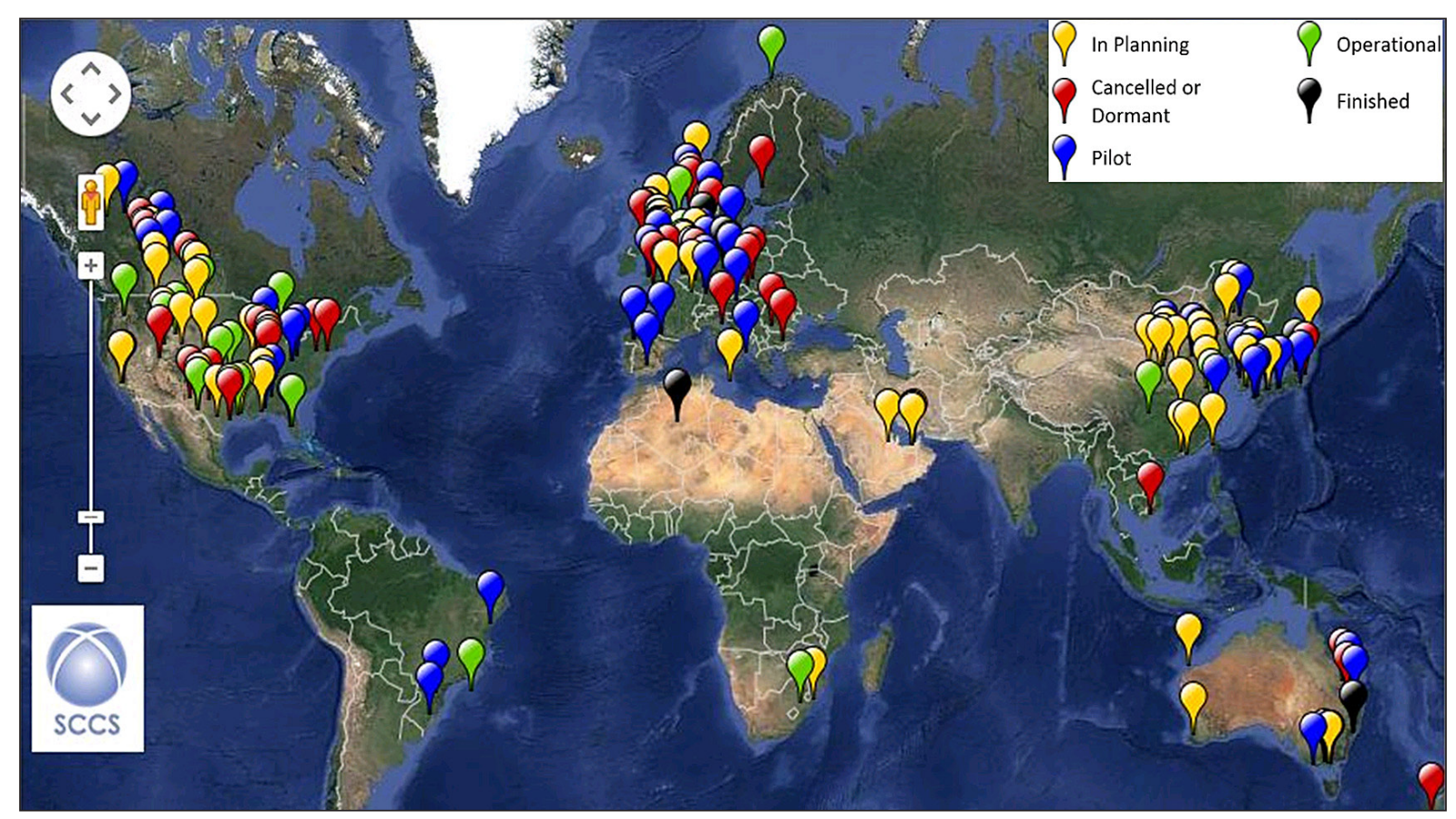

Figure 1. CSS projects map [SCCS 2016] 


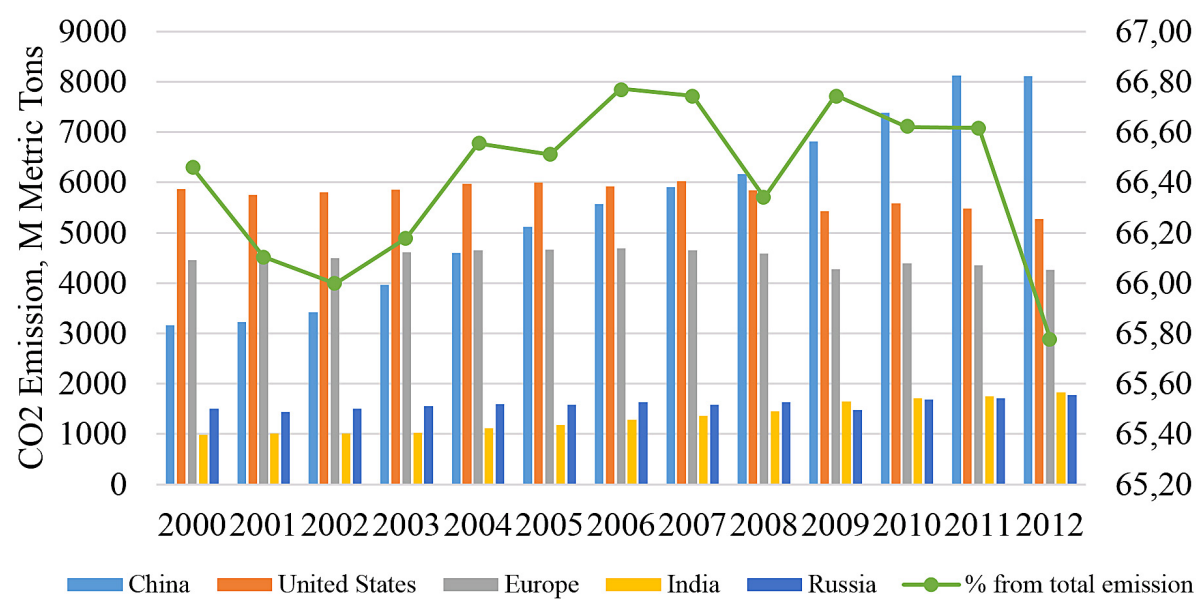

Figure 2. Top producers of $\mathrm{CO}_{2}$ emissions [EIA 2012]

\section{PERSPECTIVES OF CCS PROJECTS IMPLEMENTATION IN THE WORLD}

CCS is a combination of separate technologies (Figure 3), which can be combined with each other to create a more flexible and efficient system in various industries [McFarland et al. 2003, Cherepovitsyn et al. 2013]. In connection with the novelty of CSS, there are various approaches to determining its value [IEA 2004, McKinsey 2008]. For example, according to the forecast of McKinsey [2008] experts, there are early stage demonstration projects $(\sim 2015)$, an early commercial stage (2020) and mature commercial stage (2030). The key differences between these phases, expressed in terms CCS unit cost per 1 tonne $\mathrm{CO}_{2}$ (Table 2).

The most significant price reduction is expected in the $\mathrm{CO}_{2}$ capture process due to imperfect modern technologies of traditional fuel and raw materials. However, research in the field of alternative use of raw fuel materials (for exam- ple, coal [Maurstad et al. 2006, Holt 2003] and biomass [Rhodes and Keith 2003, Rhodes and Keith 2005, Gu and Bergman 2015] gasification), shows a high efficiency of the capture process and, therefore, lower cost technology. Thereby, today marks the launch of a number of CCS projects, which are described by Folger [2014]. However, there are no pilot projects or similar fullcycle CCS technologies in Russia.

Another important issue in the field of reducing greenhouse gas emissions and, consequently, increasing the commercial effectiveness of CSS project is the modernization of state tax policy. Morris and Mathur [2014] examine existing research focused on increasing tax rates on $\mathrm{CO} 2$ emissions in the United States. The author highlights the approach [Morris 2013a], which allows to satisfy a number of sides interested in reducing the $\mathrm{CO}_{2}$ emissions. The tax rate is proposed to be set at $\$ 16$ per ton of $\mathrm{CO}_{2}$ emissions and increase it by $4 \%$ per year due to inflation.

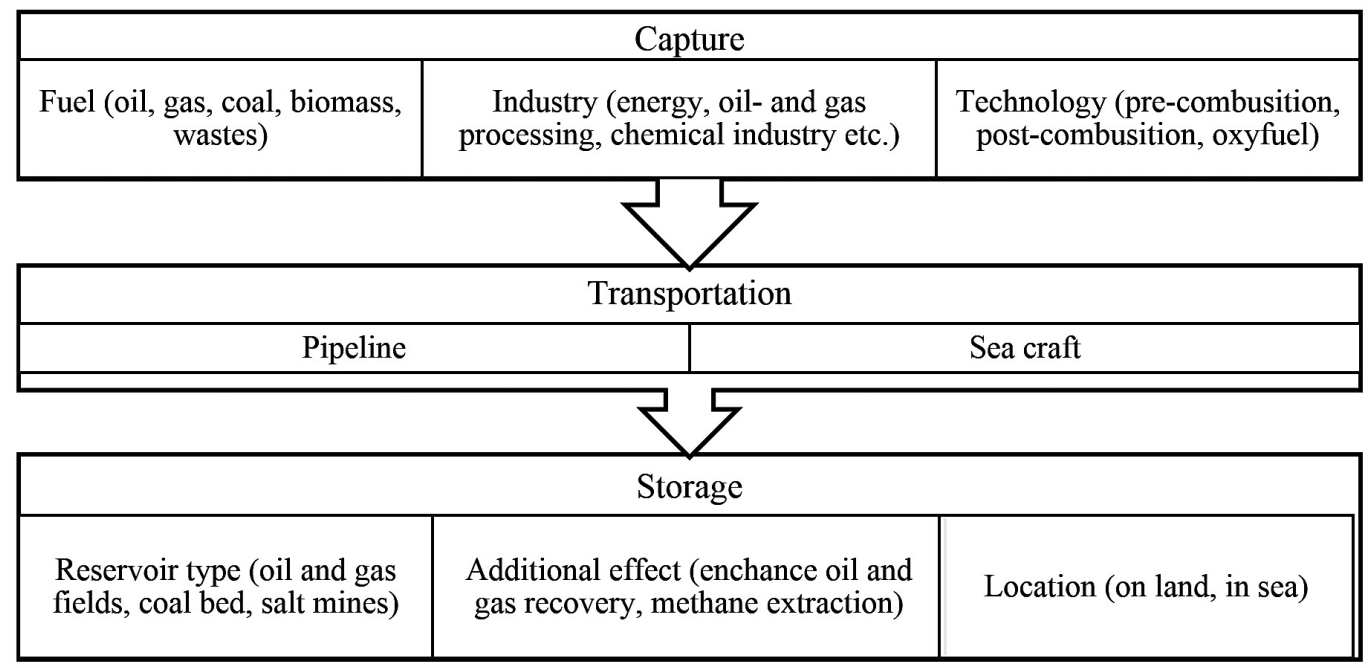

Figure 3. Scheme of CCS technology 
Table 2. The forecast of CSS value at different stages, USD/t

\begin{tabular}{|l|c|c|c|}
\hline \multicolumn{1}{|c|}{ CSS value } & Demonstration projects & Early commercial stage & Mature commercial stage \\
\hline Value of $1 \mathrm{t}$. emission reduction & $60-90$ & $35-50$ & $30-45$ \\
\hline Value of $1 \mathrm{t} . \mathrm{CO}_{2}$ capture & $51-64$ & $25-32$ & $28-43$ \\
\hline
\end{tabular}

Withana et al. [2014] explored the existing tax system in the EU environment. The authors emphasize that the effectiveness of the tax system in European countries varies widely enough, and the average share of environmental charges in GDP amounted to $2.3 \%$ (in 2011). The highest tax rate for $\mathrm{CO}_{2}$ emissions in all of Europe was introduced by Sweden (75 Euro/tonne $\mathrm{CO}_{2}$ ) [Speck 2013].

The simulation results [Golombek et al. 2009] indicate that without the introduction of adequate tax on $\mathrm{CO}_{2}$ emissions (at least $45 \$$ /Metric ton $\mathrm{CO}_{2}$ ) implementation of CCS projects in the energy sector in Europe (up to 2030) will be impossible.

The imperfection of modern technologies, as well as the absence of ongoing projects that implement the entire CSS process chain makes it difficult to develop common methods for their evaluation. However, some researchers [McFarland et al. 2003, Jacobson 2012, Mirfenderski 2008] obtained notable theoretical results. The authors of these studies agree on the fact that the estimate is approximate, and the fate of CCS will depend on the pace of technology development.

Thus, there is a growing interest in CCS issues in the world scientific literature. One of the exceptions is Russia, where the issues of such projects implementation are not considered yet, despite the fact that Russia is one of the top $\mathrm{CO}_{2}$ emission producers in the world (Figure 2).

\section{PAYBACK OF THE CCS PROJECTS}

The feasibility of CCS projects is determined by the growth of industrial production [Keller et al. 2003], which can be expressed in terms of GDP (Figure 4).

As the base for Russian industry growth forecast, the data of the Ministry of the Russian Federation Economic Development was used [2013]. Based on the fact that the volume of emissions increases according to the mathematical relation indicated in Figure 4, the minimum presumptive CO2 emissions in the range of 2016-2030 years was calculated.

Given the lack of factual data of the CCS projects functioning, the question of the effectiveness of their implementation is debatable. In this regard, a number of scientific periodicals [Greenpeace 2008, WWF 2011, IEA 2010, Van Egmond and Hekkert 2012, GCCSI 2009, IPCC 2012, Cherepovitsyn and Ilinsky 2011] were analyzed. It allowed identifying some arguments for and against the development of CCS, which are relevant for Russia.

The main driver for the development of CCS projects today is the tightening of the tax rates on CCS emissions. In addition, it is possible to store $\mathrm{CO}_{2}$ into oil fields (the most effective direction for $\mathrm{CO}_{2}$ use assessment according to McKinsey) that allows to increase the oil recovery factor, which can be an additional source of income

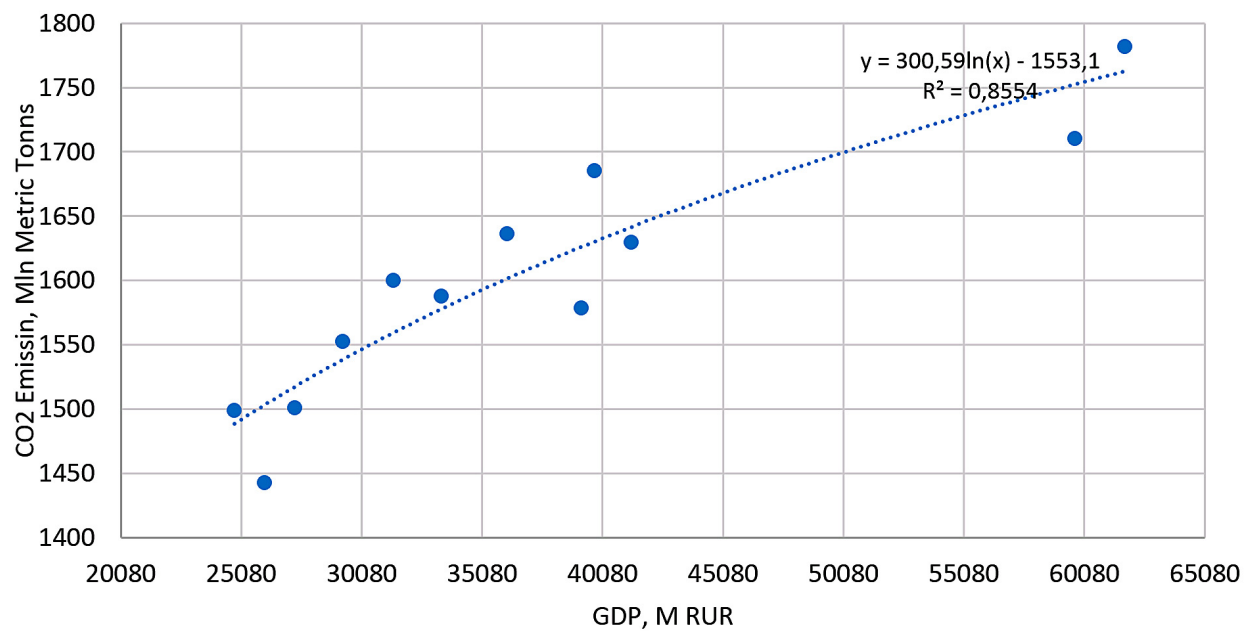

Figure 4. The relation between $\mathrm{CO}_{2}$ emissions volume and GDP of Russia (2000-2012) 
from the implementation of such projects. There are no taxes on $\mathrm{CO}_{2}$ emissions in Russia, unlike in Europe and the US, moreover the structure of energy consumption to 2030 will be unchanged (Table 3). Given these facts, it was attempted to determine the required growth of oil extraction per 1 ton of injected $\mathrm{CO}_{2}$ into the field to provide at least a break-even of the project.

The evaluation was based on information about JSC "Rosneft Oil Company" and JSC "Gazpromneft oil Company" best practice. The conversion of the ruble to the dollar was carried out at the rate of Central Bank of Russian Federation 02.06.2016 ( $1 \mathrm{USD}=77.34 \mathrm{RUR})$. The cost of oil transportation is taken equal to $5.7 \mathrm{USD} /$ barrel [Gazprom oil Company 2015]. Price per 1 barrel - 34.13 USD (06/02/2016). Cost of oil production - 3 USD/barrel. [RBC 2016]. Thus, the maximum profit is $25.43 \mathrm{USD} / \mathrm{b}$ arrel. The cost of $1 \mathrm{t}$. of $\mathrm{CO}_{2}$ storage adopted on the basis of the minimum limits specified in Table 2.

\section{ECOLOGICAL ASPECTS}

The potential of CCS projects implementation is widely discussed on the world stage (Table 4). Despite the differences in opinions, there is no denying the fact that the preservation of ecology is one of basic principles of regions' sustainable development, including the issue of $\mathrm{CO}_{2}$ emissions raise. The relevance of this problem in Russia determines by the forecast of $\mathrm{CO}_{2}$ emission volume (Figure 5) and by the absence of preconditions to changing of the country's energy sources balance structure.

By 2030, $\mathrm{CO}_{2}$ emissions in Russia will increase by $6.9-11.84 \%$, whereas, for example, in Europe it is going to be reduced to $40 \%$ of emissions in relation to 1990 [European Commission 2014].

\section{ECONOMICAL ASPECTS}

CCS projects are capital-intensive and should not be implemented with the obligatory participa-

Table 3. Forecast of energy resources consumption in Russian Federation [Ministry of the Russian Federation Economic Development 2013]

\begin{tabular}{|c|c|c|c|c|c|c|}
\hline \multirow{2}{*}{ Year } & \multirow{2}{*}{ Cases } & \multicolumn{5}{|c|}{ Energy sources, \% } \\
\cline { 2 - 8 } & & coal & oil & gas & hydro and nuclear energy & others \\
\hline \multirow{3}{*}{2020} & 1 & 15.1 & 19.2 & 52.2 & 12.5 & 1 \\
\cline { 2 - 8 } & 2 & 15.4 & $19-18.9$ & $53.1-53.4$ & $11.6-11.3$ & $0.9-1$ \\
\cline { 2 - 8 } & 3 & 15.4 & 19 & 54.2 & 10.4 & 1 \\
\hline \multirow{3}{*}{2030} & 1 & 14.4 & 19.1 & 50.3 & 15.2 & $1-1.1$ \\
\cline { 2 - 8 } & 2 & $14.1-13.9$ & $18.7-18.5$ & $52.5-52.7$ & $13.7-13.8$ & 1 \\
\hline
\end{tabular}

Table 4. Arguments in favor and against the implementation of CCS projects in Russia

\begin{tabular}{|c|c|c|}
\hline In favor & Field & Against \\
\hline $\begin{array}{l}\text { There are industries without alternatives for CCS } \\
\text { (cement manufacturing, steel industry, etc.) }\end{array}$ & \multirow{2}{*}{ Climate } & $\begin{array}{l}\text { CCS did not have time to reach the stage of maturity in } \\
\text { time to solve the problem of global warming }\end{array}$ \\
\hline $\begin{array}{l}\text { CCS can prepare a platform for the transition to } \\
\text { alternative energy }\end{array}$ & & $\begin{array}{l}\text { CCS diverts a significant amount of funds that can be } \\
\text { directed to the development of alternative energy }\end{array}$ \\
\hline $\begin{array}{l}\text { Implementation of CCS will increase the life period } \\
\text { of coal and gas energy plants }\end{array}$ & Energy & CCS significantly reduces industrial energy efficiency \\
\hline $\begin{array}{l}\text { CCS will reduce } \mathrm{CO} 2 \text { emissions without reducing } \\
\text { industry growth }\end{array}$ & \multirow{3}{*}{ Technology } & $\begin{array}{l}\text { Given the huge amounts of emissions there may not be } \\
\text { sufficient space for underground storage }\end{array}$ \\
\hline $\begin{array}{l}\text { All elements of CCS technologies have already } \\
\text { been used on an industrial scale }\end{array}$ & & Full CCS process is never used \\
\hline $\begin{array}{l}\text { There is additional effect from CCS use (enhance } \\
\text { oil recovery, increase methane recovery, etc.). }\end{array}$ & & $\begin{array}{l}\text { CCS capture process is associated with the generation of } \\
\text { waste }\end{array}$ \\
\hline $\begin{array}{l}\text { Russia should not miss the opportunity to trade on } \\
\text { the carbon market }\end{array}$ & $\begin{array}{l}\text { International } \\
\text { relationship }\end{array}$ & $\begin{array}{l}\text { Russia has no obligations under the second period } \\
\text { of the Kyoto Protocol, and internal commitments to } \\
\text { reduce emissions by } 15-20 \% \text { can be reached without } \\
\text { implementation of the CCS projects }\end{array}$ \\
\hline Russia has significant potential for $\mathrm{CO} 2$ storage & \multirow[b]{2}{*}{ Economy } & $\begin{array}{l}\text { The cost of electricity will increase dramatically in the case } \\
\text { of CCS implementation }\end{array}$ \\
\hline $\begin{array}{l}\text { Russian oil and gas infrastructure is well developed } \\
\text { that will reduce the value of CCS projects }\end{array}$ & & $\begin{array}{l}\text { There is no guarantee that an additional effect (for } \\
\text { example, enhanced oil recovery) will exceed the value of } \\
\text { CCS projects }\end{array}$ \\
\hline
\end{tabular}




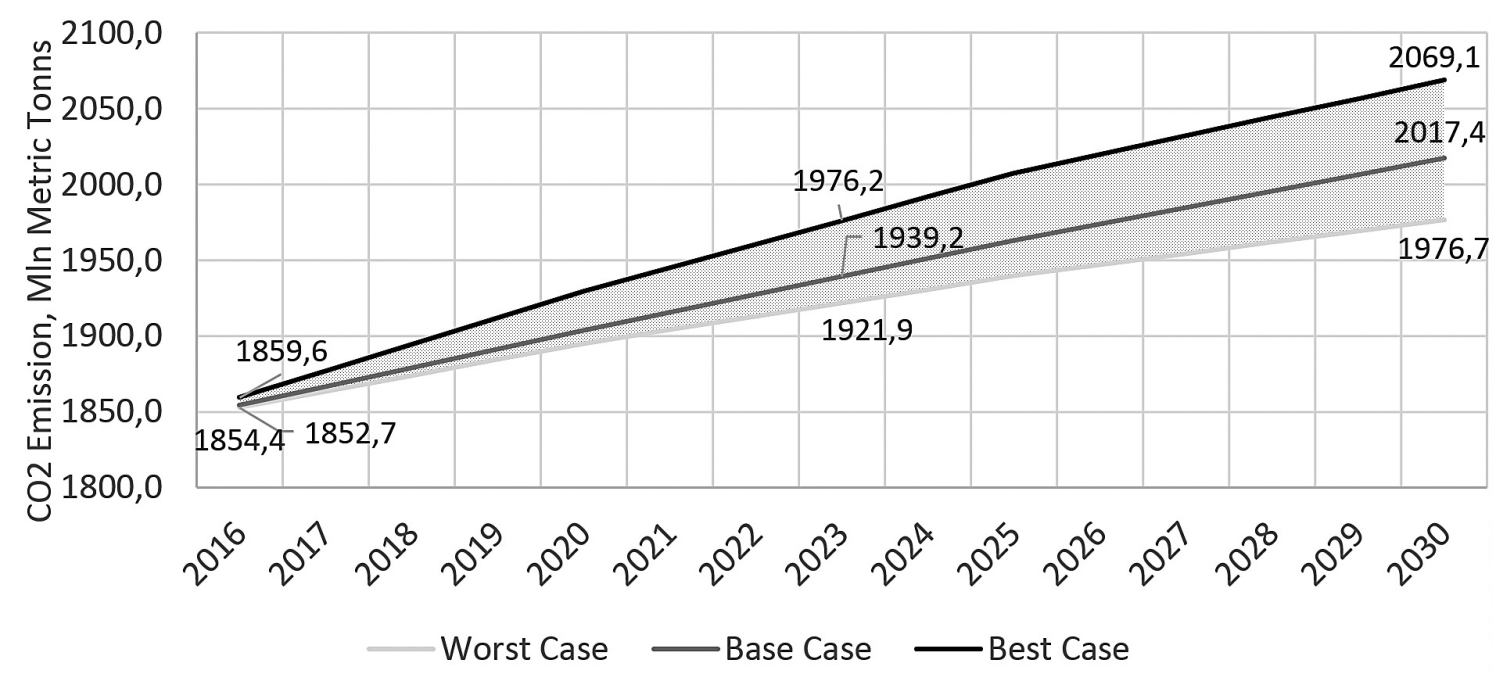

Figure 5. Forecast of Russian $\mathrm{CO}_{2}$ emissions growth

tion of the state. This is possible only at the demonstration stage, in the future, such projects must have an economic effect. Due to this, the evaluation of such projects commercial effectiveness becomes relevant.

On the base of CCS value forecast [McKinsey 2008] and the analysis of the current situation in the oil markets an approximate estimate of the required oil production growth per 1 ton of stored into the field $\mathrm{CO}_{2}$ was drawn (Figure 6).

The evaluation shows that the level of oil extraction required for the implementation of such projects is relatively high, but attainable. According to Shell [2016], the average amount of additional oil extraction in such projects is 1.8 barrels / 1 tonn of $\mathrm{CO}_{2}$. For comparison, one of the most successful CCS projects to date - The Great Plains Synfuels Plant, where 1 t. $\mathrm{CO}_{2}$ pumped into the field makes possible to extract 6.5 barrels of oil [DGC 2008]. Lost Cabin Project - 2.117 barrels/1 t. $\mathrm{CO}_{2}$ [ZERO 2016]. Weyburn-Midale project -1.846 barrels $/ 1$ t. $\mathrm{CO}_{2}$ [CCST 2016].

\section{CONCLUSIONS}

There are many discussions around the development and implementation of CCS technologies. The main arguments against CCS is inability to reduce $\mathrm{CO}_{2}$ emissions to the required level in time and unavailability of a large-scale industrial implementation. Moreover, it is difficult to predict how large volumes of stored $\mathrm{CO}_{2}$ will migrate in the underground space and how it will affect the global ecosystem after dozens and hundreds of years.

On the other hand, CCS technology will stimulate the growth of industrial energy efficiency

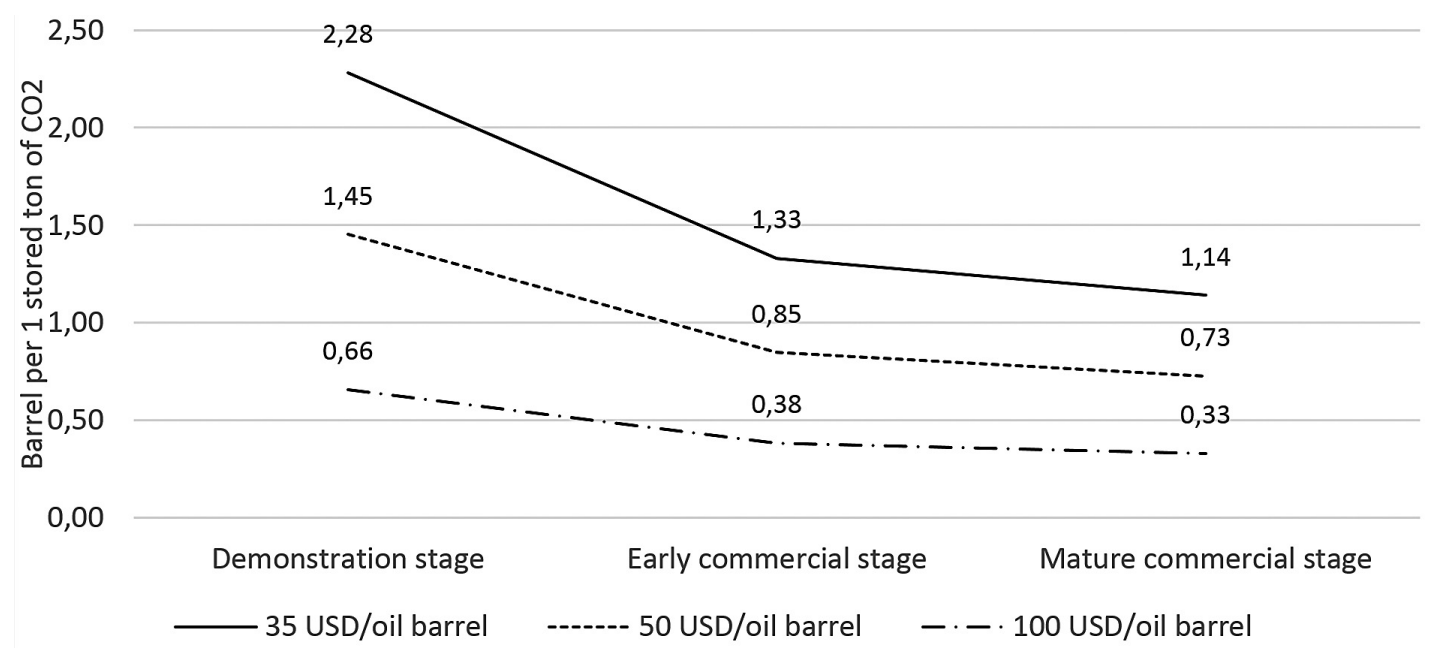

Figure 6. The required increase in barrels of oil per 1 ton of the stored $\mathrm{CO}_{2}$ 
and increase the oil and gas recovery factor. Thus, it is possible to agree that CCS technology is the way to effective resource-saving. CCS is a kind of nature-like technology, which allows to reduce human pressure on the environment. The existence of successful demonstration projects in the world should also be noted.

Russia is one of the largest $\mathrm{CO}_{2}$ emissions producers in the world. However, there are no CCS demonstration projects, no effective system of state support, no research supported by the real sector of economy, no adequate system of $\mathrm{CO}_{2}$ emissions taxes. Current and forecasted CCS value makes it potentially effective when used for enhance Russian oil fields. In addition, studies in the field of biomass and coal gasification show the possibility of a significant increase in the efficiency of $\mathrm{CO}_{2}$ capture process - the most expensive stage of the CCS projects. However, a need to take into account the fact that the implementation of CCS projects will lead to a substantial rise in the cost of electricity in Russia [Rubin 2005].

\section{Acknowledgements}

The paper is based on research carried out with the financial support of the grant of the Russian Science Foundation (Project No. 14-3800009, "The program-targeted management of the Russian Arctic zone development"). Peter the Great St. Petersburg Polytechnic University.

\section{REFERENCES}

1. Adele M. Want a pro-growth pro-environment plan? Economists agree: Tax carbon. The Brookings Institution Up Front blog, 2013a. URL: http://www. brookings.edu/blogs/up-front/posts/2013/02/07-carbon-tax-morris. (accessed 14.02.2016).

2. Borodulya V.A., Palchenko G.I., Vinogradov L.M. et al. Bioenergy - hydrogen or carbon? In: Proceedings of V Minsk International Forum on Heat and Mass Transfer, 2004. 9 p. http://www.itmo.by/ ru/conferences/mif_5/abstract/6-03.pdf (accessed 14.02.2016).

3. Burcu B. Pyrolysis: A sustainable way from waste to energy. Proceedings the 1st FOREBIOM Workshop: Potentials of Biochar to mitigate climate change. European Geosciences Union General Assembly, 2013. URL: http://www.oeaw.ac.at/forebiom/WS1lectures/SessionII_Uzun.pdf (accessed 14.02.2016).

4. CCES. Carbon Capture and Storage. Center for Climate and Energy Solutions, 2014. URL: http://
www.c2es.org/technology/factsheet/CCS (accessed 14.02.2016).

5. CCST official web site. URL: https://sequestration. mit.edu/tools/projects/weyburn.html (accessed 14.02.2016).

6. Cherepovitsyn A.E., Sidorova G.I., Smirnova N.V. The feasibility of using $\mathrm{CO}_{2}$ sequestration technologies in Russia. Oil and Gas Business, 2013, 5, 459-473 URL: http://www.ogbus.ru/authors/ CherepovitsynAE/CherepovitsynAE_1.pdf (accessed 14.02.2016).

7. Dakota Gasification Company - How it works. URL: http://www.dakotagas.com/CO2_Capture and_Storage/How_It_Works/index.html (accessed 14.02.2016).

8. Doha Climate Change Conference, Summary. Earth Negotiations Bulletin, 2012, 12(567). URL: http://www.iisd.ca/vol12/enb12567e.html (accessed 14.02.2016)

9. EIA. International Energy Statistics URL: http:// www.eia.gov/cfapps/ipdbproject/iedindex3.cfm?ti $\mathrm{d}=90 \&$ pid $=44 \&$ aid $=8 \&$ cid $=$ regions \& syid $=2000 \&$ eyid=2012\&unit=MMTCD (accessed 14.02.2016).

10. European Commission. Official web site. http://ec.europa.eu/energy/en/topics/energy-strategy/2030-energy-strategy (accessed 14.02.2016).

11. European Commission. Reference Document on Best Available Techniques (BREF) in Large Combustion Plants. Integrated Pollution Prevention and Control (IPPC), 2006. 618 pp. URL: http://ec.europa.eu/environment/ippc/brefs/lcp_ bref_0706.pdf (accessed 14.02.2016).

12. Folger P. Carbon capture and sequestration: Research, development, and demonstration at the U.S. Department of Energy, 2014. URL: https:// www.fas.org/sgp/crs/misc/R42496.pdf (accessed 14.02.2016).

13. Gazpromneft oil company quarter report, 2015. URL: http://ir.gazprom-neft.ru/fileadmin/report_files/mda_3m_2015_rus_01.pdf (accessed 14.02.2016).

14. GCCSI. Strategic analysis of the global status of carbon capture and storage. Global CCS Institute Report 3: Russia, 2009, 35 p. URL: http://cdn. globalccsinstitute.com/sites/default/files/publications/8622/strategic-analysis-global-status-ccscountry-study-russia.pdf (accessed 14.02.2016).

15. Geological disposal of carbon dioxide and radioactive waste: A comparative assessment. Monograph. L. Toth, A. Cherepovitsyn and A. Ilinsky (Eds.) Comparison of the Geological Disposal of Carbon Dioxide and Radioactive Waste in European Russia, p. 489-513. International Atomic Energy Agency, 2011; Springer Dordrecht London Heidelberg New York, p. 621. 
16. Golombek R., Greaker M., Kittelsen S. A.C., Røgeberg O., Aune F.R. Carbon capture and storage technologies in the european power market. Discussion Papers No. 603, December 2009. Statistics Norway, Research Department. URL: http://www.ssb.no/a/publikasjoner/pdf/DP/dp603. pdf (accessed 14.02.2016).

17. Greenpeace. False hope - Why carbon capture and storage won't save the climate. Greenpeace International, 2008. 44 p. URL: http://www.greenpeace. org/usa/Global/usa/report/2008/5/false-hope-whycarbon-capture.pdf (accessed 14.02.2016).

18. Holt N., Booras G., Todd D. Summary of recent IGCC studies of $\mathrm{CO}_{2}$ capture for sequestration. Gasification Technologies Conference, 2003. URL: http://www.gasification-syngas.org/uploads/eventLibrary/31HOLT_paper.pdf (accessed 14.02.2016).

19. Hongmei Gu, Bergman R. Life-cycle GHG emissions of electricity from syngas produced by pyrolyzing woody biomass. Proceedings of the 58th International Convention of Society of Wood Science and Technology, June 7-12, 2015 Jackson Lake Lodge, Grand Teton National Park, Wyoming, USA. URL: http://www.fpl.fs.fed.us/documnts/pdf2015/ fpl_2015_gu001.pdf (accessed 14.02.2016).

20. Hulme M. and Mahony M.. Climate change: What do we know about the IPCC? Progress in Physical Geography, 2010. DOI: 10.1177/0309133310373719

21. IEA - Energy technology perspectives. Scenarios and strategies to 2050. OECD/IEA, Paris, France, 2010. 710 p. URL: http://www.iea.org/publications/freepublications/publication/etp2010.pdf (accessed 14.02.2016).

22. IEA. Data from $\mathrm{CO}_{2}$ emissions from fuel combustion (2015 prelimin. edition). International Energy Agency Statistics. http:/www.iea.org/publications/ freepublications/publication/CO2_OECD_Factsheet_2015.pdf (accessed 14.02.2016).

23. IEA. Prospects for $\mathrm{CO}_{2}$ Capture and Storage. International Energy Agency, 2004. URL: https://www. iea.org/Textbase/npsum/ccsSUM.pdf (accessed 14.02.2016).

24. IPCC. Renewable energy sources and climate change mitigation. Special report, New York, USA, 2012. 1088 p. URL: http://www.ipcc.ch/ pdf/special-reports/srren/SRREN_Full_Report.pdf (accessed 14.02.2016).

25. Jacobson C.B. Economic prospects for advanced combustion technologies suited for climate change mitigation. All Theses and Dissertations (ETDs), 2012. Paper 1029. URL: http://openscholarship. wustl.edu/cgi/viewcontent.cgi?article $=2029 \&$ cont ext=etd (accessed 14.02.2016).

26. Keeling C.D. The influence of mauna loa observatory on the development of atmospheric $\mathrm{CO}_{2}$ research. In Mauna Loa Observatory: A 20th Anniversary Report. (National Oceanic and Atmospheric Administration Special Report, September 1978), edited by John Miller, pp. 36-54. Boulder, CO: NOAA Environmental Research Laboratories.

27. Keller K., Yang Z., Hall M., Bradford D.F. Carbon dioxide sequestration: When and how much? Center for Economic Policy Studies (CEPS) Working Paper No. 94. Princeton University, September 2003. URL: https://www.princeton.edu/ ceps/workingpapers/94bradford.pdf (accessed 14.02.2016).

28. Khlebnikov V.N., Zobov P.M., Khamidullin I.R., Ruzanova Ju.F., Ivanov E.V., Vinokurov V.A. Perspective regions for hothouse gas sequestration project realization in Russia // Bash. chem. journal, 2009, 2, 73-80. URL: http://cyberleninka.ru/ article/n/perspektivnye-regiony-dlya-osuschestvleniya-proektov-po-hraneniyu-parnikovyh-gazovv-rossii (accessed 14.02.2016).

29. L'Orange Seigo S., Dohle S., Siegrist M. Public perception of carbon capture and storage (CCS): A review. Renewable and Sustainable Energy Reviews, 38, 2014, 848-863. doi:10.1016/j.rser.2014.07.017

30. Leung D. Y.C., Caramanna G., Maroto-Valer M.M. An overview of current status of carbon dioxide capture and storage technologies. Renewable and Sustainable Energy Reviews, 39, 2014, 426-443. doi:10.1016/j.rser.2014.07.093

31. Maurstad O., Herzog H., Bolland O., Beér J. Impact of coal quality and gasifier technology on IGCC performance. Proceedings of 8th International Conference on Greenhouse Gas Control Technologies, 2006. Trondheim. URL: https:// sequestration.mit.edu/pdf/GHGT8_Maurstad.pdf (accessed 14.02.2016).

32. McFarland J.R., Herzog H.J., Reilly J.M. Economic modeling of the global adoption of carbon capture and sequestration technologies. Proceedings of 6th International Conference on Greenhouse Gas Control Technologies (GHGT-6), 2003. Vol. II, J. Gale and Y. Kaya (Eds.), Elsevier, pp 1083-1088.

33. McKinsey \& Company. Carbon Capture \& Storage: Assessing the Economics. - McKinsey \& Co., 2008. 53 p. URL: http://assets.wwf.ch/downloads/ mckinsey2008.pdf (accessed 14.02.2016).

34. Meakin S. The rio earth summit: summary of the united nations conference on environment and development. Science and Technology Division, November 1992. URL: http://publications.gc.ca/ Collection-R/LoPBdP/BP/bp317-e.htm (accessed 14.02.2016)

35. Ministry of the Russian Federation Economic Development, 2013. Forecast of Long-Term SocioEconomic Development of the Russian Federation for the Period until 2030. URL http://government. 
$\mathrm{ru} / \mathrm{media} /$ files/41d457592e04b76338b7.pdf (accessed 14.02.2016).

36. Mirfendereski Y. Techno-economic assessment of carbon capture and sequestration technologies in the fossil fuel-based power sector of the global energyeconomy system. Technische Universität Berlin Energy Engineering Institute, 2008. Master Thesis. URL: https://www.pik-potsdam.de/members/edenh/ theses/master_yasaman (accessed 14.02.2016).

37. Morris A., Mathur A. A carbon tax in broader U.S. fiscal reform: Design and distributional issues. Center for climate and energy solutions, May 2014. URL: http://www.c2es.org/publications/carbontax-broader-us-fiscal-reform-design-distributionalissues (accessed 14.02.2016).

38. RBC multimedia holding official web site. URL: http://www.rbc.ru/business/13/01/2016/5694fb659 a79471c576b43f5 (accessed 14.02.2016).

39. Rhodes S.J., Keith D.W. 2003. Biomass energy with geological sequestration of $\mathrm{CO}_{2}$ : Two for the price of one? Greenhouse Gas Control Technologies, 2, 1371-1376. URL: http://scholar.harvard.edu/files/ davidkeith/files/55.rhodes.2003.biomasswithsequestration.f.pdf (accessed 14.02.2016).

40. Rhodes S.J., Keith D.W. 2005. Engineering economic analysis of biomass IGCC with carbon capture and storage. Biomass and Bioenergy 29, 440-450. URL: http://keith.seas.harvard.edu/ papers/67.Rhodes.2005.BiomassCCS.e.pdf (accessed 14.02.2016).

41. Rubin E.S. et al. Comparative assessments of fossil fuel power plants with $\mathrm{CO}_{2}$ capture and storage. Proceedings of the GHGT-7 Conference, V.1, Elsevier, 2005. 9 p. URL: http://repository.cmu.edu/ cgi/viewcontent.cgi? article $=1082 \&$ context $=$ epp (accessed 14.02.2016).
42. SCCS. Scottish carbon capture \& storage official web site. URL: http://www.sccs.org.uk/expertise/ global-ccs-map (accessed 14.02.2016).

43. Shell official web site. http://www.shell.ca/en/ aboutshell/our-business-tpkg/upstream/oil-sands/ quest/technology.html (accessed 14.02.2016).

44. Speck S. Carbon taxation - two decades of experience and future prospects. Carbon Management, 4(2), 2013, 171-183. DOI: 10.4155/cmt.12.81

45. Tcvetkov P., Strizhenok A. Ecological and economic efficiency of peat fast pyrolysis projects as an alternative source of raw energy resources. Journal of Ecological Engineering, 17(1), 2016, 56-62, DOI: 10.12911/22998993/61190

46. Van Egmond S., Hekkert M.P. Argument map for carbon capture and storage. International Journal of Greenhouse Gas Control, 2012. 12 p. URL: http://dx.doi.org/10.1016/j.ijggc.2012.08.010 (accessed 14.02.2016).

47. Withana S., Brink P., Illes A., Nanni S., Watkins E. Environmental tax reform in Europe: Opportunities for the future, A report by the Institute for European Environmental Policy (IEEP) for the Netherlands Ministry of Infrastructure and the Environment. Final Report. Brussels, 2014. URL: http://www. ieep.eu/assets/1397/ETR_in_Europe___Final_report_of_IEEP_study_-_30_May_2014.pdf (accessed 14.02.2016).

48. WWF. The Energy Report, 100\% Renewable Energy by 2050. - WWF/Ecofys/OMA, Gland, Switzerland, 2011. 256 p. URL: http://www.wwf.or.jp/ activities/lib/pdf_climate/green-energy/WWF_EnergyVisionReport.pdf (accessed 14.02.2016).

49. ZERO official web site. URL: http://www.zeroco2. no/projects/lost-cabin (accessed 14.02.2016). 